\title{
Sesquiterpenoids from the Stem Bark of Aglaia simplicifolia and Their Cytotoxic Activity against B16-F10 Melanoma Skin Cancer Cell
}

\author{
Ghina Izdihar $^{1}$, Al Arofatus Naini ${ }^{1}$, Desi Harneti ${ }^{1}$, Rani Maharani ${ }^{1,2}$, Nurlelasari Nurlelasari ${ }^{1}$, Tri \\ Mayanti $^{1}$, Agus Safari ${ }^{1}$, Kindi Farabi ${ }^{1}$, Unang Supratman ${ }^{1,2^{\star}}$, Mohamad Nurul Azmi ${ }^{3}$, and Yoshihito \\ Shiono $^{4}$ \\ ${ }^{1}$ Department of Chemistry, Faculty of Mathematics and Natural Sciences, Universitas Padjadjaran, \\ Jl. Raya Bandung-Sumedang Km. 21, Jatinangor, Sumedang 45363, Indonesia \\ ${ }^{2}$ Central Laboratory of Universitas Padjadjaran, Jl. Raya Bandung-Sumedang Km. 21, Jatinangor, Sumedang 45363, Indonesia \\ ${ }^{3}$ School of Chemical Sciences, Universiti Sains Malaysia, 11800 Minden, Penang, Malaysia \\ ${ }^{4}$ Department of Bioresources Engineering, Faculty of Agriculture, Yamagata University, Tsuruoka-shi, Yamagata 997-8555, Japan
}

* Corresponding author:

email: unang.supratman@unpad.ac.id

Received: August 13, 2021

Accepted: October 25, 2021

DOI: $10.22146 / \mathrm{ijc} .68383$

\begin{abstract}
Four sesquiterpenoid derivatives, i.e., 4 $\beta, 10 \alpha$-dihydroxyaromadendrane (1), caryophyllenol-II (2), senecrassidiol (3), and clovane-2 $\beta, 9 \alpha$-diol (4) have been isolated from the stem bark of Aglaia simplicifolia. The chemical structures of compounds 1-4 were determined based on spectroscopic data, including one and two-dimensional NMR and mass spectroscopy. In addition, these sesquiterpenoids 1-4, were also tested for their cytotoxic activity against B16-F10 melanoma skin cancer cell lines through in vitro assay. Among the isolated compounds 1-4, compound 1 showed the highest activity with an $I C_{50}$ value of $44.8 \mu \mathrm{g} / \mathrm{mL}$, suggesting the presence of a cyclopropane ring that plays an essential role in cytotoxic activity against B16-F10 melanoma skin cancer cell lines.
\end{abstract}

Keywords: Aglaia simplicifolia; cytotoxic activity; B16-F10 cell lines; sesquiterpenoid; Meliaceae

\section{- INTRODUCTION}

Sesquiterpenoids are secondary metabolites derived from three isoprene units 2-methyl-1,3-diene with 15 carbon atoms and 24 hydrogens per molecule $\left(\mathrm{C}_{15} \mathrm{H}_{24}\right)[1]$. Sesquiterpenoids were classified using the number of cyclic formed by modification of the cyclization reaction and rearrangement of the carbon skeleton. For example, acyclic, monocyclic, bicyclic, and tricyclic sesquiterpenoids, with several types of cyclic, cyclopropane, cyclobutane, cyclopentane, cyclohexane, and cycloheptane [2-3]. The characteristic of sesquiterpenoids are oils with volatile properties but less volatile than monoterpenoids, the main components of essential oil with more pungent odors, and can be found in plants, mainly in higher plants [3].

Currently, there are more than 10,000 known types of sesquiterpenoids in nature [1]. The diversity of sesquiterpenoids comes from farnesyl pyrophosphate (FPP) as a precursor, which has three double bonds, so the carbon chain is more flexible, so makes the structural diversity in the carbon skeleton $\left(\mathrm{C}_{15}\right)$ sesquiterpenoid [4]. In addition, the presence of functional groups and substituents arranged regionally and stereospecifically made sesquiterpenoids diverse skeletons [5]. Sesquiterpenoids are very useful because these compounds have many biological activities such as antiinflammatory [6], antibacterial [7], antioxidant [8], antitumor [9-10], and antimalarial [11] agents. For example, artemisinin is a sesquiterpenoid lactone isolated from Artemisia annua and has been used as a malarial drug [12].

Aglaia is a kind of higher plant in the tropical rainforest. Aglaia is the largest genus that belongs to the Meliaceae family, which contains more than 150 species

Ghina Izdihar et al. 
and about 65 species grown only in Indonesia. The Aglaia genus has been identified in Southern Asia's tropical and subtropical rainforest, Northern Australia, and the pacific region. The distributions of the Aglaia genus can be found in many countries, such as India, Thailand, Vietnam, Malaysia, and Indonesia [13-14]. Traditionally, the bark of Aglaia has been used as traditional Indonesian herbal medicine for healing fever, influenza, cough, and other skin diseases [3,13-14].

A. simplicifolia is one of Aglaia plants that has been phytochemically investigated before, and it has been proven to contain ergosterol peroxide, stigmasterol, and senecrassidiol with cytotoxic activity against HeLa cervical cancer [15-16]. So far, about twenty-three sesquiterpenoids have been investigated separately from the Aglaia species [13]. Therefore, to observe the cytotoxic constituents of Indonesian Aglaia plants against B16-F10 melanoma skin cancer cell lines, we report herein the isolation, structure elucidation, and cytotoxic evaluation of four types of aromadendrane, caryolan, clovane, and caryophyllene sesquiterpenoids 1-4 from A. simplicifolia.

\section{- EXPERIMENTAL SECTION}

\section{Materials}

The stem bark of A. simplicifolia was collected in January 2016 at Bogor Botanical Garden, Bogor, West Java Province, Indonesia. The voucher specimen was authenticated by the staff of the Bogoriense Herbarium, Research Centre for Biology, Indonesian Institute of Science, Bogor, Indonesia, and deposited at that herbarium (No. BO-1295311).

Organic solvents such as $n$-hexane, ethyl acetate, methanol, $n$-butanol, methylene chloride, and acetone were purchased from the Kristata Gemilang Company, Bandung in technical quality and distilled. The B16-F10 cell was acquired from American Type Culture Collection (ATCC ${ }^{\circ}{\text { CRL- } 6475^{\mathrm{m}} \text {, }}$, Manassas, Virginia, USA). The medium used was Dulbecco's Modified Eagle's Medium (DMEM high glucose) (Cat. No. 11965118, Gibco, New York, USA) added with 10\% Fetal Bovine Serum (FBS) (Cat. No. 10082147, Gibco) and 1\% Penicillinstreptomycin (Cat. No. 15140112, Gibco). Cell incubation was conducted at $37^{\circ} \mathrm{C}$ in a $5 \% \mathrm{CO}_{2}$ incubator (Cat. No.
8000DH, Thermo Fisher Scientific, Waltham, Massachusetts, USA).

\section{Instrumentation}

The IR spectra were obtained on Perkin Elmer Spectrum 100 FT-IR spectrometer using $\mathrm{NaCl}$ plate. The mass spectra were obtained with Waters Q-TOF Xevo mass spectrometer instrument. The NMR spectra were recorded on the JEOL JNM-ECX500R/S1 spectrometer at $500 \mathrm{MHz}$ for ${ }^{1} \mathrm{H}$ and $125 \mathrm{MHz}$ for ${ }^{13} \mathrm{C}$ with TMS as an internal standard. The column chromatography was performed on silica gel 60 (Merck, 70-230 and 230400 mesh) and octadecyl silane (Fuji Sylisia, 200-400 mesh). The TLC analyses were conducted with TLC silica gel $60 \mathrm{GF}_{254}$ (Merck, $0.25 \mathrm{~mm}$ ) using various solvent systems, and spot detection was obtained by spraying with $10 \% \mathrm{H}_{2} \mathrm{SO}_{4}$ in EtOH, followed by heating and irradiating under ultraviolet-visible light at wavelength 254 and $365 \mathrm{~nm}$, respectively.

\section{Procedure}

\section{Extraction and isolation}

A $1.01 \mathrm{~kg}$ of dried bark A. simplicifolia was extracted with methanol $(12 \mathrm{~L})$ at room temperature for $3 \mathrm{~d}$. The methanol extract was evaporated with a rotary evaporator at $40{ }^{\circ} \mathrm{C}$ under reduced pressure to yield a residue of the concentrated methanol extract (194.9 g). Then, this residue was dissolved in water and portioned successively with $n$-hexane $(10 \mathrm{~L})$, ethyl acetate $(10 \mathrm{~L})$, and $n$-butanol $(10 \mathrm{~L})$. The evaporated these extracts resulted in $n$-hexane (14.5 g), ethyl acetate (28.0 g), and $n$-butanol (14.5 g), respectively. The ethyl acetate extract $(28.0 \mathrm{~g})$ was separated by vacuum liquid chromatography (VLC) on silica gel G60 using a gradient solvent of $n$ hexane-ethyl acetate, $20 \%$ gradient, then ethyl acetatemethanol, $10 \%$ gradient to give eight fractions (A-H). The E fraction ( $1.54 \mathrm{~g}$ ) was column chromatographed on silica gel (70-230 mesh) using an isocratic solvent of $n$ hexane:ethyl acetate (8:2) to yield eleven fractions (E1E11). Furthermore, the E7 fraction ( $58.6 \mathrm{mg}$ ) was column chromatographed on silica gel (230-400 mesh), eluted with methylene chloride:ethyl acetate (9:1) to give five fractions (E7.A-E7.E). The E7.B fraction $(32.7 \mathrm{mg}$ ) was column chromatographed on silica gel (230-400 mesh) 


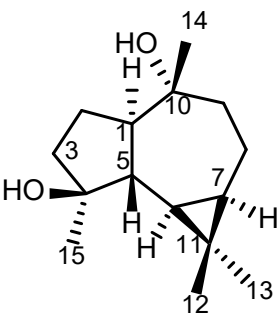

1

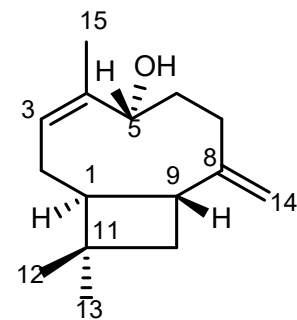

2

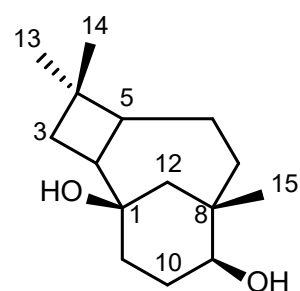

3

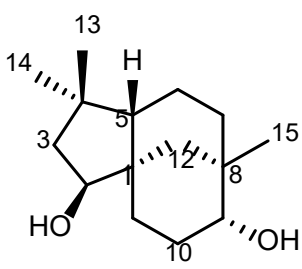

4

Fig 1. Chemical structures of compounds 1-4

eluted with $n$-hexane:methylene chloride:acetone (2:7.5.0:0.5) to give four fractions (E7.B1-E7.B4). Furthermore, the E7.B3 fraction was column chromatographed on silica gel (230-400 mesh) eluted with $n$-hexane:methylene chloride: acetone (3.0:6.5:0.5) to yield compound $\mathbf{1}(7.8 \mathrm{mg})$.

The E8 fraction (115.3 mg) was column chromatographed on silica gel (230-400 mesh) using a isocratic elution of $n$-hexane:methylene chloride:acetone (2.0:7.5:0.5) to give three fractions (E8.A-E8.C). The E8.A fraction $(30.3 \mathrm{mg}$ ) was column chromatographed on silica gel (230-400 mesh) eluted with $n$-hexane:methylene chloride:acetone (2.0:7.5:0.5) to yield compound 2 (5.5 mg). The E8.C fraction $(70.3 \mathrm{mg}$ ) was column chromatographed on silica gel (230-400 mesh) eluted with $n$-hexane: methylene chloride:ethyl acetate (0.5:9.0:0.5) to give three fractions (E8.C1-E8.C3). Finally, the E8.C1 fraction (50.8 $\mathrm{mg}$ ) was further column chromatographed on octadecyl silane (ODS) eluted with methanol:water (5:5) to obtained compound 3 (7.4 mg) and compound 4 (4.2 mg). 4ß,10a-Dihydroxyaromadendrane (1). Pale yellow oil; $[\alpha]_{\mathrm{D}}^{26.1^{\circ}}-25.0$ (c $\left.0.2, \mathrm{CHCl}_{3}\right) ; \mathrm{IR}(\mathrm{NaCl}) v_{\max } 3362,2853$, 1456, 1378, and $1054 \mathrm{~cm}^{-1} ;{ }^{1} \mathrm{H}-\mathrm{NMR}$ (acetone- $d_{6}, 500$ MHz): $\delta_{\mathrm{H}} 1.82(1 \mathrm{H}, \mathrm{dd}, J=10.0,18.5 \mathrm{~Hz}, \mathrm{H}-1), 1.57(2 \mathrm{H}$, $\mathrm{m}, \mathrm{H}-2), 1.67(2 \mathrm{H}, \mathrm{m}, \mathrm{H}-3), 1.12(1 \mathrm{H}, \mathrm{m}, \mathrm{H}-5), 0.41(1 \mathrm{H}$, dd, $J=9.5,11.0 \mathrm{~Hz}, \mathrm{H}-6), 0.56(1 \mathrm{H}, \mathrm{dd}, J=9.5,11.0 \mathrm{~Hz}$, H-7), $0.9(1 \mathrm{H}, \mathrm{m}, \mathrm{H}-8 \mathrm{a}), 2.05(1 \mathrm{H}, \mathrm{m}, \mathrm{H}-8 \mathrm{~b}), 1.57(1 \mathrm{H}, \mathrm{m}$, $\mathrm{H}-9 \mathrm{a}), 1.67$ (1H, m, H-9b), 0.98 (3H, s, H-12), 0.99 (3H, s, $\mathrm{H}-13), 1.1$ (3H, s, H-14), 1.16 (3H, s, H-15); ${ }^{13} \mathrm{C}-\mathrm{NMR}$ (acetone- $d_{6}, 125 \mathrm{MHz}$ ) see Table 1 . HR-TOFMS $\mathrm{m} / \mathrm{z}$ found $261.1854[\mathrm{M}+\mathrm{Na}]^{+}$, (calculated for $\mathrm{C}_{15} \mathrm{H}_{26} \mathrm{O}_{2} \mathrm{Na}$, $\mathrm{m} / \mathrm{z} 261.1831)$.

Caryophyllenol-II (2). Pale yellow oil; $[\alpha]_{\mathrm{D}}^{26.1^{\circ}}-54.2$ (c $\left.0.2, \mathrm{CHCl}_{3}\right)$; IR ( NaCl) $v_{\max } 3362,3088,1721,1613,1386$,
1463 , and $1078 \mathrm{~cm}^{-1} ;{ }^{1} \mathrm{H}-\mathrm{NMR}$ (acetone- $\left.d_{6}, 500 \mathrm{MHz}\right) \delta_{\mathrm{H}}$ 2.07 (1H, m, H-1), $1.94(1 \mathrm{H}, \mathrm{m}, \mathrm{H}-2 \mathrm{a}), 2.17(1 \mathrm{H}, \mathrm{m}, \mathrm{H}-$ b), $5.54(1 \mathrm{H}, \mathrm{td}, J=1.2,10.2 \mathrm{~Hz}, \mathrm{H}-3), 4.86(1 \mathrm{H}, \mathrm{dd}, J=$ $4.2,10.2 \mathrm{~Hz}, \mathrm{H}-5 \mathrm{a}), 2.67(1 \mathrm{H}, \mathrm{q}, J=12.6,10.2 \mathrm{~Hz}, \mathrm{H}-5 \mathrm{~b})$, $1.71(1 \mathrm{H}, \mathrm{m}, \mathrm{H}-6), 1.82(1 \mathrm{H}, \mathrm{m}, \mathrm{H}-7 \mathrm{a}), 1.6(1 \mathrm{H}, \mathrm{m}, \mathrm{H}-$ 7b), $2.33(1 \mathrm{H}, \mathrm{m}, \mathrm{H}-9), 1.68(1 \mathrm{H}, \mathrm{m}, \mathrm{H}-10 \mathrm{a}), 1.51(1 \mathrm{H}$, m, H-10b), 1.26 (3H, s, H-12), 1.01 (3H, s, H-13), 4.8 $(1 \mathrm{H}, \mathrm{q}, J=2.4 \mathrm{~Hz}, \mathrm{H}-14 \mathrm{a}), 4.27(1 \mathrm{H}, \mathrm{t}, J=2.4 \mathrm{~Hz}, \mathrm{H}-14 \mathrm{~b})$, $1.02(3 \mathrm{H}, \mathrm{s}, \mathrm{H}-15) ;{ }^{13} \mathrm{C}-\mathrm{NMR}$ (acetone- $d_{6}, 125 \mathrm{MHz}$ ) see Table 1; HR-TOFMS $m / z$ found $221.1737[\mathrm{M}+\mathrm{H}]^{+}$, (calculated for $\mathrm{C}_{15} \mathrm{H}_{25} \mathrm{O}, \mathrm{m} / z$ 221.1702).

Senecrassidiol (3). Pale yellow oil; IR ( $\mathrm{NaCl}) v_{\max } 3369$, 2917, 1451, 1378, $1019 \mathrm{~cm}^{-1}$; ${ }^{1} \mathrm{H}-\mathrm{NMR}\left(\mathrm{CDCl}_{3}, 500\right.$ $\mathrm{MHz}) \delta_{\mathrm{H}} 2.18(1 \mathrm{H}, \mathrm{t}, J=12.0 \mathrm{~Hz}, \mathrm{H}-2), 1.15(1 \mathrm{H}, \mathrm{d}, J=$ $3.5 \mathrm{~Hz}, \mathrm{H}-2 \mathrm{a}), 1.13(1 \mathrm{H}, \mathrm{d}, J=4.0 \mathrm{~Hz}, \mathrm{H}-2 \mathrm{~b}), 1.8(1 \mathrm{H}, \mathrm{m}$, $\mathrm{H}-5), 1.46(1 \mathrm{H}, \mathrm{m}, \mathrm{H}-6 \mathrm{a}), 1.33(1 \mathrm{H}, \mathrm{m}, \mathrm{H}-6 \mathrm{~b}), 1.38(1 \mathrm{H}$, m, H-7a), 1.35 (1H, m, H-7b), $3.44(1 \mathrm{H}, \mathrm{t}, J=3.0 \mathrm{~Hz}, \mathrm{H}-$ 9), $2.01(1 \mathrm{H}, \mathrm{m}, \mathrm{H}-10 \mathrm{a}), 1.74(1 \mathrm{H}, \mathrm{m}, \mathrm{H}-10 \mathrm{~b}), 1.61(1 \mathrm{H}$, d, $J=5.0 \mathrm{~Hz}, \mathrm{H}-11 \mathrm{a}), 1.48(1 \mathrm{H}, \mathrm{d}, J=3.0 \mathrm{~Hz}, \mathrm{H}-11 \mathrm{~b}), 1.4$ $(1 \mathrm{H}, \mathrm{d}, J=13.5 \mathrm{~Hz}, \mathrm{H}-12 \mathrm{a}), 1.13(1 \mathrm{H}, \mathrm{d}, J=13.5 \mathrm{~Hz}, \mathrm{H}-$ 12b), 1.01 (3H, s, H-13), 1.0 (3H, s, H-14), 0.92 (3H, s, $\mathrm{H}-15) ;{ }^{13} \mathrm{C}-\mathrm{NMR}\left(\mathrm{CDCl}_{3}, 125 \mathrm{MHz}\right)$ see Table 1; HRTOFMS $m / z$ found $256.1956\left[\mathrm{M}+\mathrm{H}_{2} \mathrm{O}\right]^{+}$, (calculated for $\mathrm{C}_{15} \mathrm{H}_{26} \mathrm{O}_{2}, m / z$ 238.1905).

Clovane-2ß,9a-diol (4). Amorphous powder; IR $(\mathrm{NaCl}) v_{\max } 3340,2918,1544,1416$, and $1019 \mathrm{~cm}^{-1} ;{ }^{1} \mathrm{H}-$ $\operatorname{NMR}\left(\mathrm{CDCl}_{3}, 500 \mathrm{MHz}\right) \delta_{\mathrm{H}} 3.78(\mathrm{dd}, J=10.5,5.5 \mathrm{~Hz}, \mathrm{H}-$ 2), $1.5(\mathrm{dd}, J=12.0,10.0 \mathrm{~Hz}, \mathrm{H}-3 \mathrm{a}), 1.72(\mathrm{dd}, J=12,5.5 \mathrm{~Hz}$, $\mathrm{H}-3 \mathrm{~b}), 1.41(1 \mathrm{H}, \mathrm{m}, \mathrm{H}-5), 1.43(1 \mathrm{H}, \mathrm{m}, \mathrm{H}-6 \mathrm{a}), 1.31(1 \mathrm{H}$, m, H-6b), 1.35 (1H, m, H-7a), 1.09 (1H, m, H-7b), 3.31 (br s, H-9), 1.99 (1H, m, H-10a), $1.61(1 \mathrm{H}, \mathrm{m}, \mathrm{H}-10 \mathrm{~b})$, $1.66(1 \mathrm{H}, \mathrm{m}, \mathrm{H}-11 \mathrm{a}), 1.08(1 \mathrm{H}, \mathrm{m}, \mathrm{H}-11 \mathrm{~b}), 0.9$ (br d, $J=$ $12.5 \mathrm{~Hz}, \mathrm{H}-12 \mathrm{a}), 1.54$ (d, $J=12.5 \mathrm{~Hz}, \mathrm{H}-12 \mathrm{~b}), 0.85(3 \mathrm{H}$, s, H-13), 1.03 (3H, s, H-14), 0.95 (3H, s, H-15); ${ }^{13} \mathrm{C}-\mathrm{NMR}$ 
Table $1 .{ }^{13} \mathrm{C}$-NMR data of compound 1-4

\begin{tabular}{lcccc}
\hline \multirow{2}{*}{$\begin{array}{l}\text { Position } \\
\text { carbon }\end{array}$} & \multicolumn{4}{c}{ Compounds } \\
\cline { 2 - 5 } & $1^{*}($ mult. $)$ & $\delta_{\mathrm{C}}($ mult. $)$ & $\delta_{\mathrm{C}}($ mult. & $\delta_{\mathrm{C}}($ mult. $)$ \\
\hline 1 & $56.8(\mathrm{~d})$ & $50.2(\mathrm{~d})$ & $70.8(\mathrm{~s})$ & $44.2(\mathrm{~s})$ \\
2 & $23.9(\mathrm{t})$ & $27.5(\mathrm{t})$ & $38.1(\mathrm{~d})$ & $80.9(\mathrm{~d})$ \\
3 & $41.3(\mathrm{t})$ & $127.0(\mathrm{~d})$ & $33.5(\mathrm{t})$ & $47.5(\mathrm{t})$ \\
4 & $79.2(\mathrm{~s})$ & $137.4(\mathrm{~s})$ & $35.2(\mathrm{~s})$ & $37.1(\mathrm{~s})$ \\
5 & $48.0(\mathrm{~d})$ & $69.9(\mathrm{~d})$ & $43.9(\mathrm{~d})$ & $50.4(\mathrm{~d})$ \\
6 & $28.2(\mathrm{~d})$ & $34.4(\mathrm{t})$ & $20.4(\mathrm{t})$ & $20.6(\mathrm{t})$ \\
7 & $26.6(\mathrm{~d})$ & $31.0(\mathrm{t})$ & $42.5(\mathrm{t})$ & $33.1(\mathrm{t})$ \\
8 & $20.1(\mathrm{t})$ & $154.5(\mathrm{~s})$ & $39.4(\mathrm{~s})$ & $34.7(\mathrm{~s})$ \\
9 & $44.7(\mathrm{t})$ & $42.7(\mathrm{~d})$ & $72.3(\mathrm{~d})$ & $75.0(\mathrm{~d})$ \\
10 & $73.5(\mathrm{~s})$ & $41.8(\mathrm{t})$ & $28.2(\mathrm{t})$ & $26.0(\mathrm{t})$ \\
11 & $19.2(\mathrm{~s})$ & $33.6(\mathrm{~s})$ & $35.4(\mathrm{t})$ & $26.3(\mathrm{t})$ \\
12 & $15.9(\mathrm{q})$ & $23.1(\mathrm{q})$ & $34.1(\mathrm{t})$ & $35.5(\mathrm{t})$ \\
13 & $29.7(\mathrm{q})$ & $31.2(\mathrm{q})$ & $20.9(\mathrm{q})$ & $25.4(\mathrm{q})$ \\
14 & $19.8(\mathrm{q})$ & $110.57(\mathrm{t})$ & $30.6(\mathrm{q})$ & $31.4(\mathrm{q})$ \\
15 & $24.0(\mathrm{q})$ & $16.7(\mathrm{q})$ & $26.7(\mathrm{q})$ & $28.3(\mathrm{q})$ \\
\hline
\end{tabular}

$\left({ }^{\star}\right.$ Measured in acetone- $\left.d_{6}\right)$

$\left({ }^{*}\right.$ Measured in $\mathrm{CDCl}_{3}$ )

$\left(\mathrm{CDCl}_{3}, 125 \mathrm{MHz}\right)$ see Table 2; HR-TOFMS $\mathrm{m} / z$ found 221.2009 $[\mathrm{M}+\mathrm{H}]^{+}$, (calculated for $\mathrm{C}_{15} \mathrm{H}_{26} \mathrm{O}_{2}, \quad \mathrm{~m} / \mathrm{z}$ 220.2011).

\section{Cytotoxic activity assay}

Cell viability was assessed with Presto Blue reagent (Thermo Fisher Scientific, Uppsala, Sweden) to evaluate various resazurin-based cell types' viability rapidly and quantitatively proliferation using live-cell reduction capabilities. When cells are alive and healthy, they maintain a reduced environment in their cytosol. Reducing resazurin (blue) works as a cell viability indicator by using absorbance or fluorescent outputs to reduce resorufin (purple). The conversion is proportional to the number of metabolically active cells. Briefly, B16F10 cell lines were grown in 70\% confluent were harvested and counted, then diluted with complete culture RPMI medium. The cells then were transferred into 96 wellplates with a total of 170,000 cells/well. After overnight growth, the cells were treated with increasing concentrations of compounds 1-4 (3.91, 7.81, 15.63, $31.25,62.50,125,250,5,000 \mathrm{ppm}$ ) with co-solvent $2 \%$ (v/v) DMSO in PBS. Cisplatin was used as the positive control. All samples were incubated at $37^{\circ} \mathrm{C}$ in a $5 \% \mathrm{CO}_{2}$ incubator for $24 \mathrm{~h}$. After incubation, the medium was immediately replaced by $10 \mu \mathrm{L}$ PrestoBlue reagent in a $90 \mu \mathrm{L}$ RPMI medium. The plates were incubated for 1$2 \mathrm{~h}$ until resorufin was formed (color changes from blue to purple). The absorbance was measured at $570 \mathrm{~nm}$ using a microplate reader. The $\mathrm{IC}_{50}$ value is the concentration for $50 \%$ growth inhibition. The percentage of cytotoxicity compared to untreated cells was determined with the equation given below. A plot of $\%$ cytotoxicity versus sample concentrations was used to calculate the concentration, which showed 50\% cytotoxicity $\left(\mathrm{IC}_{50}\right)$ [17-18]. All assay and analyses were each run in duplicate, and all were averaged.

\section{- RESULTS AND DISCUSSION}

The ethyl acetate extract of the stem bark of $A$. simplicifolia was subjected to repeated column chromatography to afford four sesquiterpenoids, 1-4 (Fig. 1). Compound 1 was obtained as a pale yellow oil. The molecular formula was established with HR-TOFMS as $\mathrm{C}_{15} \mathrm{H}_{26} \mathrm{O}_{2}$ from the molecular ion peak of 261.1854 $\left([\mathrm{M}+\mathrm{Na}]^{+}\right.$calculated for $\mathrm{C}_{15} \mathrm{H}_{26} \mathrm{O}_{2} \mathrm{Na} \mathrm{m} / z 261.1831$ in the HR-TOF-MS (Fig. S1), indicating three degrees of 
unsaturation. The IR spectrum (Fig. S2) showed the absorption band of the hydroxyl group $\left(3362 \mathrm{~cm}^{-1}\right), \mathrm{C}-\mathrm{H}$ stretching of aliphatics (2959 and $2853 \mathrm{~cm}^{-1}$ ), gemdimethyl (1456 and $1378 \mathrm{~cm}^{-1}$ ), and $\mathrm{C}-\mathrm{O}$ stretching $\left(1054 \mathrm{~cm}^{-1}\right)$. The ${ }^{1} \mathrm{H}-\mathrm{NMR}$ spectrum (Fig. S3) showed the presence of four tertiary methyls at $\delta_{\mathrm{H}} 0.98\left(\mathrm{CH}_{3}-12\right), 0.99$ $\left(\mathrm{CH}_{3}-13\right), 1.07\left(\mathrm{CH}_{3}-14\right)$, and $1.16 \mathrm{ppm}\left(\mathrm{CH}_{3}-15\right)$. The ${ }^{13} \mathrm{C}$-NMR spectrum (Fig. S4) showed fifteen carbon signals classified by their chemical shifts and DEPT spectra as four methyls, four methylenes, four methines, and three quaternary carbons (including two oxygenated quaternary carbon). Two oxygenated quaternary carbons were bound with the hydroxyl group, marked with a more deshielded chemical shift value [19]. Based on the type of carbon in compound $\mathbf{1}$, there are no double bonds, so three degrees of unsaturation originated from the tricyclic sesquiterpenoid framework, namely aromadendrane-type sesquiterpenoid. The specific characteristic of aromadendrane-type sesquiterpenoid is the presence of a gem-dimethyl cyclopropane ring marked with one quaternary carbon at $\delta_{\mathrm{C}} 19.2 \mathrm{ppm}$. Based on the data spectrum ${ }^{1} \mathrm{H}$-NMR, ${ }^{13} \mathrm{C}-\mathrm{NMR}$, DEPT $135^{\circ}$, optical rotation, and agreed with the literature, compound 1 was determined as the known compound $4 \beta, 10 \alpha-$ dihydroxyaromadendrane, that was reported for the first time from A. Simplicifolia.

Compound 2 was obtained in a pale yellow oil. The molecular formula was established with HR-TOF-MS as $\mathrm{C}_{15} \mathrm{H}_{24} \mathrm{O}$ from the molecular ion peak of 221.1737 $\left([\mathrm{M}+\mathrm{H}]^{+}\right.$calculated for $\mathrm{C}_{15} \mathrm{H}_{25} \mathrm{O}, \mathrm{m} / z 221.1702$ in the HRTOF-MS (Fig. S5), indicating four degrees of unsaturation. IR spectrum (Fig. S6) showed the absorption band of the hydroxyl group $\left(3362 \mathrm{~cm}^{-1}\right), \mathrm{C}-\mathrm{H}$ $s p^{2}\left(3088 \mathrm{~cm}^{-1}\right)$, gem-dimethyl (1386 and $\left.1463 \mathrm{~cm}^{-1}\right), \mathrm{C}=\mathrm{C}$ double bonds (1721 and $\left.1613 \mathrm{~cm}^{-1}\right)$, and $\mathrm{C}-\mathrm{O}$ stretching $\left(1078 \mathrm{~cm}^{-1}\right)$. The ${ }^{1} \mathrm{H}-\mathrm{NMR}$ spectrum (Fig. S7) showed the presence of three tertiary methyls at $\delta_{\mathrm{H}} 1.01\left(\mathrm{CH}_{3}-13\right)$, $1.02\left(\mathrm{CH}_{3}-15\right)$, and $1.26\left(\mathrm{CH}_{3}-12\right)$. The ${ }^{13} \mathrm{C}-\mathrm{NMR}$ spectrum (Fig. S8) showed fifteen carbon signals classified based on their chemical shifts and DEPT spectra as three methyls, four methylenes, two methines, one quaternary carbon, four olefinic carbons (including two quaternary carbon, one methylene, and one oxygenated methine.
Based on the type of carbon in compound 2, there are four degrees of unsaturation originating from two double bonds and bicyclic sesquiterpenoid framework, namely caryophyllene-type sesquiterpenoid. Based on the data spectrum ${ }^{1} \mathrm{H}-\mathrm{NMR},{ }^{13} \mathrm{C}-\mathrm{NMR}$, DEPT $135^{\circ}$, optical rotation, and agreed with the literature, compound 2 was determined as the known compound caryophyllenol-II.

Compound 3 was obtained as pale yellow oil. The molecular formula was established with HR-TOF-MS as $\mathrm{C}_{15} \mathrm{H}_{26} \mathrm{O}_{2}$ from the molecular ion peak of 256.1956 ([M$\left.\mathrm{H}_{2} \mathrm{O}\right]^{+}$calculated for $\left.\mathrm{C}_{15} \mathrm{H}_{26} \mathrm{O}_{2}, m / z 238.1905\right)$ in the HRTOF-MS (Fig. S9), indicating three degrees of unsaturation. The IR spectrum (Fig. S10) showed the absorption band of the hydroxyl group $\left(3369 \mathrm{~cm}^{-1}\right)$, C$\mathrm{H} s p^{3}\left(2917 \mathrm{~cm}^{-1}\right)$, gem-dimethyl (1451 and $\left.1378 \mathrm{~cm}^{-1}\right)$, and $\mathrm{C}-\mathrm{O}$ stretching $\left(1019 \mathrm{~cm}^{-1}\right)$. The ${ }^{1} \mathrm{H}-\mathrm{NMR}$ spectrum (Fig. S11) showed the presence of three tertiary methyls at $\delta_{\mathrm{H}} 0.92\left(\mathrm{CH}_{3}-15\right), 1.0\left(\mathrm{CH}_{3}-14\right)$, and $1.01\left(\mathrm{CH}_{3}-13\right)$. An oxygenated methine proton signal at $\delta_{\mathrm{H}} 3.44 \mathrm{ppm}(1 \mathrm{H}, \mathrm{t}$, $J=3.0 \mathrm{~Hz}$ ) was also observed in the ${ }^{1} \mathrm{H}$-NMR spectrum. The ${ }^{13} \mathrm{C}$-NMR (Fig. S12) spectrum showed fifteen carbon signals classified by their chemical shifts and DEPT spectra as three methyls, six methylenes, four methines (including one oxygenated methine), and two quaternary carbons. Based on the type of carbon in compound 3, there are three degrees of unsaturation originating from the tricyclic sesquiterpenoid framework, namely caryolane-type sesquiterpenoid with specific characteristic is $\beta$-methano bridge between two quaternary carbons $\mathrm{C}-1$ and $\mathrm{C}-8$. Based on the data spectrum ${ }^{1} \mathrm{H}-\mathrm{NMR},{ }^{13} \mathrm{C}-\mathrm{NMR}$, DEPT $135^{\circ}$, optical rotation, and agreed with the literature, compound 3 was determined as the known compound caryolan-1,9-diol known as a senecrassidiol.

Compound 4 was obtained as an amorphous powder. The molecular formula was established with HR-TOF-MS as $\mathrm{C}_{15} \mathrm{H}_{26} \mathrm{O}_{2}$ from the molecular ion peak of 221.2009 $\left([\mathrm{M}+\mathrm{H}]^{+}\right.$calculated for $\mathrm{C}_{15} \mathrm{H}_{26} \mathrm{O}_{2} \mathrm{~m} / z 220.2011$ in the HR-TOF-MS (Fig. S13), indicating three degrees of unsaturation. The IR spectrum (Fig. S14), showed the absorption band of the hydroxyl group $\left(3340 \mathrm{~cm}^{-1}\right)$, C$\mathrm{H}$ stretching of aliphatics $\left(2918\right.$ and $\left.2850 \mathrm{~cm}^{-1}\right)$, gem- 
dimethyl (1544 and $1416 \mathrm{~cm}^{-1}$ ), and $\mathrm{C}-\mathrm{O}$ stretching $\left(1015 \mathrm{~cm}^{-1}\right)$. The ${ }^{1} \mathrm{H}-\mathrm{NMR}$ spectrum (Fig. S15), showed the presence of three tertiary methyls at $\delta_{\mathrm{H}} 0.85\left(\mathrm{CH}_{3}-13\right)$, $1.02\left(\mathrm{CH}_{3}-14\right)$, and $0.95\left(\mathrm{CH}_{3}-15\right)$. In addition, two oxygenated methine proton signals were observed at $\delta_{\mathrm{H}}$ $3.31(1 \mathrm{H}, \mathrm{m})$ and $\delta_{\mathrm{H}} 3.77(1 \mathrm{H}, \mathrm{m})$. The DEPT and HMQC experiments (Fig. S17-S18), could differentiate the 15 atoms of carbon in the ${ }^{13} \mathrm{C}-\mathrm{NMR}$ (Fig. S16) into three methyls, six methylenes, three methines (including two oxygenated methine carbons), and three quaternary carbons. The type of carbon in compound 4 shows no double bonds, so it has three degrees of unsaturation originating from the tricyclic sesquiterpenoid framework. The remaining three degrees of unsaturation were consistent with clovane-type sesquiterpenoid skeleton [20].

The position of functional groups in compound 4 was clarified from the ${ }^{1} \mathrm{H}-{ }^{1} \mathrm{H}$ COSY and $\mathrm{HMBC}$ experiments, and the results are shown in Fig. 2. The ${ }^{1} \mathrm{H}-$ ${ }^{1} \mathrm{H}$ COSY spectrum of 4 (Fig. S19) showed correlations in $\mathrm{H}_{2}-\mathrm{H}_{3}, \mathrm{H}_{5}-\mathrm{H}_{6}-\mathrm{H}_{7}$, and $\mathrm{H}_{9}-\mathrm{H}_{10}-\mathrm{H}_{11}$, supporting the presence of rings $\mathrm{A}, \mathrm{B}$, and $\mathrm{C}$ in the clovane-type sesquiterpenoid skeleton. The skeleton of clovane-type sesquiterpenoid was determined by HMBC correlation (Fig. S20) of tertiary methyls. The correlations of $\mathrm{CH}_{3}-13$ $\left(\delta_{\mathrm{H}} 0.85\right)$ to $\mathrm{C}-14\left(\delta_{\mathrm{C}} 31.44\right), \mathrm{C}-4\left(\delta_{\mathrm{C}} 37.14\right), \mathrm{C}-5\left(\delta_{\mathrm{C}} 50.42\right)$, and $\mathrm{C}-3\left(\delta_{\mathrm{C}} 47.54\right)$ and correlation of $\mathrm{CH}_{3}-14\left(\delta_{\mathrm{H}} 1.02\right)$ to $\mathrm{C}-13\left(\delta_{\mathrm{C}} 25.42\right), \mathrm{C}-4\left(\delta_{\mathrm{C}} 37.14\right), \mathrm{C}-5\left(\delta_{\mathrm{C}} 50.42\right)$, and C-3 $\left(\delta_{\mathrm{C}} 47.54\right)$, showed that $\mathrm{C}-13$ and $\mathrm{C}-14$ are gem-dimethyl groups attached to C-4 quaternary carbon. The correlations of methylene protons at $\delta_{\mathrm{H}} 1.50$ and $1.72(\mathrm{H}-$ $3)$ to $\mathrm{C}-2\left(\delta_{\mathrm{C}} 80.91\right), \mathrm{C}-1\left(\delta_{\mathrm{C}} 44.19\right), \mathrm{C}-4\left(\delta_{\mathrm{C}} 37.14\right)$, and C$5\left(\delta_{\mathrm{C}} 50.42\right)$, whereas an oxygenated proton at $\delta_{\mathrm{H}} 3.78(\mathrm{H}-$ $2)$ was correlated to $C-12\left(\delta_{C} 35.51\right)$, indicated that the partial structure of 4 contains cyclopentane ring at C-1, C-2, C-3, C-4, and C-5 with the presence of hydroxyl group located in C-2. The other methyl group was determined by the strong correlation between $\mathrm{CH}_{3}-15$ $\left(\delta_{\mathrm{H}} 0.95\right)$ to $\mathrm{C}-7\left(\delta_{\mathrm{C}} 33.11\right), \mathrm{C}-9\left(\delta_{\mathrm{C}} 75.07\right)$, and C-12 $\left(\delta_{\mathrm{C}}\right.$ $35.51)$ showed that $\mathrm{C}-15$ attached to $\mathrm{C}-8$ of quaternary carbon. In addition, the correlation of another oxygenated proton at $\delta_{\mathrm{H}} 3.31(\mathrm{H}-9)$ to $\mathrm{C}-11$ and $\mathrm{C}-12$ and supported by the correlation of $\delta_{\mathrm{H}} 1.35(\mathrm{H}-7)$ to C$9\left(\delta_{\mathrm{C}} 75.07\right)$ and $\delta_{\mathrm{H}} 1.61(\mathrm{H}-10)$ to $\mathrm{C}-9\left(\delta_{\mathrm{C}} 75.07\right)$. This correlation indicated that the hydroxyl group was located in C-9. Furthermore, a correlation between protons at $\delta_{\mathrm{H}} 1.54(\mathrm{H}-12)$ to $\mathrm{C}-5, \mathrm{C}-1, \mathrm{C}-7, \mathrm{C}-8$, and C11 indicated the location of $\mathrm{C}-12$ between two quaternary carbons $\mathrm{C}-1$ and $\mathrm{C}-8$, which connected the ring $\mathrm{B}$ and $\mathrm{C}$ to form the skeleton of the bicyclononane bridge. The relative stereochemistry of compound 4 was supported by NOESY correlations (Fig. S21). The results displayed that correlation of $\mathrm{H}-5$ ( $\beta$-oriented) with $\mathrm{CH}_{3-}$ 13 , and methylene proton oxygenated $\mathrm{H}-2$ ( $\alpha$-oriented) with $\mathrm{CH}_{3}-14$ suggested $\mathrm{CH}_{3}-13$ was $\beta$-oriented while $\mathrm{CH}_{3}-14$ was $\alpha$-oriented, whereas hydroxyl group at $\mathrm{C}-2$ was $\beta$-oriented. The correlations of $\mathrm{H}-5$ ( $\beta$-oriented) with $\mathrm{H}-10$, and $\mathrm{H}-10$ ( $\beta$-oriented) with oxygenated methylene proton (H-9), proposed that $\mathrm{H}-9$ was $\beta$ oriented and the other hydroxyl group at C-9 was $\alpha-$ oriented (Fig. 2). The detailed examination of the NMR spectral data and comparison with those reported for $\mathrm{c}$ lovane-2 $\beta, 9 \alpha$-diol [21] showed that the structures of these two compounds are very similar. Compound 2 was isolated for the first time in genus Aglaia. Therefore, the structure of compound $\mathbf{4}$ was identified as a clovane$2 \beta, 9 \alpha$-diol.

The cytotoxic activities of the isolated compounds 1-4 were evaluated against the B16-F10 melanoma skin cancer cell lines according to a method described [22]. Cisplatin $(12.9 \mu \mathrm{g} / \mathrm{mL})$ was used as a positive control.

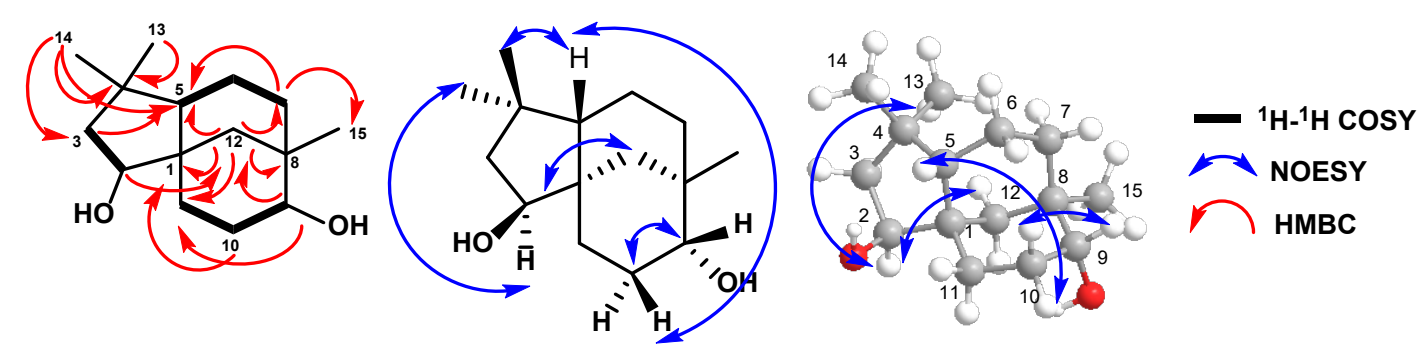

Fig 2. Selected $\mathrm{HMBC},{ }^{1} \mathrm{H}-{ }^{1} \mathrm{H}-\mathrm{COSY}$, and NOESY correlations of compound 4 
Table 2. Cytotoxic activity of compound 1-3 against B16F10 melanoma skin cancer cell lines

\begin{tabular}{lc}
\hline Compounds & $\begin{array}{c}\mathrm{IC}_{50} \\
(\mu \mathrm{g} / \mathrm{mL})\end{array}$ \\
\hline $4 \beta, 10 \alpha$-dihydroxyaromadendrane (1) & 44.8 \\
Caryophyllenol-ii (2) & 483.2 \\
Senecrassidiol (3) & 327.6 \\
Clovane-2 $\beta, 9 \alpha$-diol (4) & 176.6 \\
Cisplatin $(+)$ & 12.9 \\
\hline
\end{tabular}

The results are shown in Table 2. Among all sesquiterpenoid compounds, 4 $\beta, 10 \alpha$-dihydroxyaroma dendrane (1) showed the strongest cytotoxic activity with $\mathrm{IC}_{50}$ values of $44.8 \mu \mathrm{g} / \mathrm{mL}$, while compound (2) showed the lowest activity with an $\mathrm{IC}_{50}$ value of $483.2 \mu \mathrm{g} / \mathrm{mL}$. This result shows that the value of cytotoxic activity against B16-F10 melanoma skin cancer cells is influenced by the presence of a cyclopropane ring and $\alpha$-oriented hydroxyl group. The cyclopropane ring and hydroxyl group can increase cytotoxic activity. The $4 \beta, 10 \alpha$-dihydroxy aromadendrene compound from the stem bark of Aglaia harmsiana can inhibit the growth of MCF-7 breast cancer cells with an $\mathrm{IC}_{50}$ value of $8.4 \mu \mathrm{M}$ [3]. At the same time, the presence of an olefinic group in compound (2) decreases the cytotoxic activity. These results indicated that the cytotoxic activity of sesquiterpenoids is affected by the presence of a cyclopropane ring and $\alpha$-oriented hydroxyl group that plays an important role in cytotoxic activity.

\section{- CONCLUSION}

Four type sesquiterpenoid compounds, $4 \beta, 10 \alpha-$ dihydroxyaromadendrane (1), caryophylenol-II (2), senecrassidiol (3), and clovane-2 $\beta, 9 \alpha$-diol (4) were isolated from ethyl acetate extract of the stem bark of $A$. simplicifolia. Compound (1) was reported from $A$. simplicifolia for the first time, while compound (4) itself was isolated from genus Aglaia for the first time. Compounds 1-4 were evaluated for their cytotoxic activity against B16-F10 melanoma skin cancer cell lines. Among the sesquiterpenoids, compound (1) showed the strongest cytotoxic activity with $\mathrm{IC}_{50}$ values $44.8 \mu \mathrm{g} / \mathrm{mL}$, while compound (2) showed the lowest activity. These results indicated that the cytotoxic activity of sesquiterpenoids is affected by the presence of a cyclopropane ring and $\alpha$-oriented hydroxyl group that plays an important role in cytotoxic activity.

\section{- ACKNOWLEDGMENTS}

This research was financially supported by the Ministry of Education and Culture, Innovative and Research Council, Indonesia, Higher Education Basic Research Grant, No. 1207/UN6.3.1/PT.00/2021 by Desi Harneti and Academic Leadership Grant from Universitas Padjadjaran, Indonesia (No: 1959/UN6.3.1/PT.00/2021) by Unang Supratman.

\section{- REFERENCES}

[1] Çelik, K., Toğar, B., Türkez, H., and Taşpinar, N., 2014, In vitro cytotoxic, genotoxic, and oxidative effect of acyclic sesquiterpene farnesene, Turk. J. Biol., 38, 253-259.

[2] Jaeger, R., and Cuny, E., 2016, Terpenoids with special pharmacological significance: A review, Nat. Prod. Commun., 11 (9), 1373-1390.

[3] Milawati, H., Sukmawati, W., Harneti, D., Maharani, R., Nurlelasari, N., Hidayat, A.T., Darwati, D., Supratman, U., and Shiono, Y., 2020, Cytotoxic sesquiterpenoids from the stem bark of Aglaia harmsiana (Meliaceae), Indones. J. Chem., 20 (6), 1448-1454.

[4] Degenhardt, J., Köllner, T.G., and Gershenzon, J., 2009, Monoterpene and sesquiterpene synthases and the origin of terpene skeletal diversity in plants, Phytochemistry, 70 (15-16), 1621-1637.

[5] Gong, D.Y., Chen, X.Y., Guo, S.X., Wang, B.C., and Li, B., 2021, Recent advances and new insights in biosynthesis of dendrobine and sesquiterpenes, Appl. Microbiol. Biotechnol., 105 (18), 6597-6606.

[6] Jeena, K., Liju, V., and Kuttan, R., 2013, Antioxidant, anti-inflammatory and antinociceptive activities of essential oil from ginger, Indian J. Physiol. Pharmacol., 57 (1), 51-62.

[7] Ishnava, K.B., Chauhan, J.B., and Barad, M.B., 2013, Anticariogenic and phytochemical evaluation of Eucalyptus globulus Labill., Saudi J. Biol. Sci., 20 (1), 69-74.

[8] Ornano, L., Venditti, A., Ballero, M., Sanna, C., Quassinti, L., Bramucci, M., Lupidi, G., Papa, F., 
Vittori, S., Maggi, F., and Bianco, A., 2013, Chemopreventive and antioxidant activity of the chamazulene-rich essential oil obtained from Artemisia arborescens L. growing on the Isle of La Maddalena, Sardinia, Italy, Chem. Biodivers., 10 (8), 1464-1474.

[9] Feraz, R.P.C., Cardozo, G.M.B., da Silva T.B., Fontes, J.E.N., Prata, A.P.N., Carvalho, A.A., Moraes, M.O., Pessoa, C., Costa, E.V., and Bezerra, D.P., 2013, Antitumour properties of the leaf essential oil of Xylopia frutescens Aubl. (Annonaceae), Food Chem., 141 (1), 196-200.

[10] Park, K.R., Nam, D., Hun, H.M., Le, S.G., Jang, H.J., Sethi, G., Cho, S.K., and Ahn, K.S., 2011, $\beta-$ Caryophyllene oxide inhibits growth and induces apoptosis through the suppression of PI3K/AKT/ mTOR/S6K1 pathways and ROS-mediated MAPKs activation, Cancer Lett., 312 (2), 178-88

[11] Awouafack, M.D., Tane, P., Kuete, V., and Eloff, J.N., 2013, "Sesquiterpenes from the medicinal plants of Africa" in Medicinal Plant Research in Africa, Eds. Kuete, V., Elsevier, Oxford, 33-103.

[12] Milawati, H., Harneti, D., Maharani, R., Nurlelasari, N., Hidayat, A.T., Azmi, M.N., Shiono, Y., and Supratman, U., 2019, Caryophyllene-type sesquiterpenoids from the stembark of Aglaia harmsiana and their cytotoxic activity against MCF7 breast cancer cells, Molekul, 14 (2), 126-132.

[13] Harneti, D., and Supratman, U., 2021, Phytochemistry and biological activities of Aglaia species, Phytochemistry, 181, 112540.

[14] Sianturi, J., Purnamasari, M., Darwati, Harneti, D., Mayanti, D., Supratman, U., Awang, K., and Hayashi, H., 2015, New bisamide compounds from the bark of Aglaia eximia (Meliaceae), Phytochem. Lett., 13, 297301.

[15] Kurniasih, N., Supriadin, A., Harneti, D., Abdulah, R., Mohamad Taib, M.N.A., and Supratman, U., 2021, Ergosterol peroxide and stigmasterol from the stembark of Aglaia simplicifolia (Meliaceae) and their cytotoxic against HeLa cervical cancer cell lines, J. Kim. Valensi, 7 (1), 46-51.

[16] Kurniasih, N., Supriadin, A., Fajar, M., Abdulah, R., Harneti, D., Supratman, U., and Mohamad Taib, M.N.A., 2019, Cytotoxic sesquiterpenoid compound from the stembark of Aglaia simplicifolia (Meliaceae), J. Phys.: Conf. Ser., 1402 (5), 055037.

[17] Camarillo, I.G., Xiao, F., Madhivanan, S., Salameh, T., Nichols, M., Reece, L.M., Leary, J.F., Otto, K.J., Natarajan, A., Ramesh, A., and Sundararajan, R., 2014, "Low and High Voltage Electrochemotherapy for Breast Cancer: An in vitro Model Study" in Electroporation-Based Therapies for Cancer, Eds. Sundararajan, R., Woodhead Publishing, Cambridge, UK, 55-102.

[18] Machana, S., Weerapreeyakul, N., Barusrux, S., Nonpunya, A., Sripanidkulchai, B., and Thitimetharoch, T., 2011, Cytotoxic and apoptotic effect of six herbal plants against the human hepatocarcinoma (HepG2) cell line, Chin. Med., 6 (1), 39.

[19] Moreira, I.C., Lago, J.H., Young, M.C.M., and Roque, N.F., 2003, Antifungal aromadendrane sesquiterpenoids from the leaves of Xylopia brasiliensis, J. Braz. Chem. Soc., 14, 828-831.

[20] Le Bideau, F., Kousara, M., Chen, L., Wei, L., and Dumas, F., 2017, Tricyclic sesquiterpenes from marine origin, Chem. Rev., 117 (9), 6110-6159.

[21] Chang, Y.C., Chiang, C.C., Chang, Y.S., Chen, J.J., Wang, W.H., Fang, L.S., Chung, H.M., Hwang, T.L., and Sung, P.J., 2020, Novel caryophyllane-related sesquiterpenoids with anti-inflammatory activity from Rumphella antipathes (Linnaeus, 1758), Mar. Drugs, 18 (11), 554.

[22] Xu, M., McCanna, D.J., and Sivak, J.G., 2015, Use the viability reagent PrestoBlue in comparison with alamarBlue and MTT to assess the viability of human corneal epithelial cells, J. Pharmacol. Toxicol. Methods, 71, 1-7. 